\title{
A Hawaiian Tropical Dry Forest Regenerates: Natural Regeneration of Endangered Species under Biocultural Restoration
}

\author{
Reko Libby ${ }^{1}$, Aimee Y. Sato ${ }^{1}$, Lehua Alapai ${ }^{2}$, Wilds Pihanui Brawner ${ }^{3}$, Yvonne Yarber Carter ${ }^{2}$, \\ Keoki Apokolani Carter ${ }^{4}$, Kekaulike Tomich ${ }^{2}$ and Tamara Ticktin ${ }^{1, *}$
}

Citation: Libby, R.; Sato, A.Y.; Alapai, L.; Brawner, W.P.; Carter, Y.Y.; Carter,

K.A.; Tomich, K.; Ticktin, T. A

Hawaiian Tropical Dry Forest Regenerates: Natural Regeneration of Endangered Species under Biocultural Restoration. Sustainability 2022, 14, 1159. https://doi.org/ $10.3390 /$ su14031159

Academic Editors: Julio Campo,

Christian P. Giardina and

Rodolfo Dirzo

Received: 24 November 2021

Accepted: 14 January 2022

Published: 20 January 2022

Publisher's Note: MDPI stays neutral with regard to jurisdictional claims in published maps and institutional affiliations.

Copyright: (C) 2022 by the authors. Licensee MDPI, Basel, Switzerland. This article is an open access article distributed under the terms and conditions of the Creative Commons Attribution (CC BY) license (https:// creativecommons.org/licenses/by/ $4.0 /)$.
1 School of Life Sciences, University of Hawai'i at Mānoa, 3190 Maile Way, Honolulu, HI 96822, USA; libbyr@hawaii.edu (R.L.); aimeeysato@gmail.com (A.Y.S.)

2 Ho'ola Ka Makana'ā o Ka'ūpūlehu, Hawai'i Forest Industry Association, O’okala, HI 96774, USA; lehuaalapai@gmail.com (L.A.); keoki@trylookinside.com (Y.Y.C.); kukuiohiwai@gmail.com (K.T.)

3 Aloha 'Āina, Aloha Ka'ūpūlehu, Hawai'i Forest Industry Association, O’okala, HI 96774, USA; wilds.hfia@hawaiiforest.org

4 Ho'ohele Mea Lā’au, Hawai'i Forest Industry Association, O’okala, HI 96774, USA; trylookinside@icloud.com * Correspondence: ticktin@hawaii.edu

\begin{abstract}
Tropical dry forests (TDFs) are among the most at-risk ecosystems globally. In Hawai' $i$, more than $45 \%$ of TDF species are threatened or endangered. Despite decades of active TDF restoration, there remains limited information on the potential for long-term success, since there are few studies of natural regeneration. We assess natural regeneration of endangered plants at Ka'ūpūlehu dryland forest, a Hawaiian biocultural restoration initiative. Drawing on 6 annual censuses we (1) assess rates and patterns of natural regeneration across species and as a function of rainfall and (2) identify bottlenecks. Our surveys document natural recruits of 11 of the 12 endangered species first outplanted 15-20 years ago. Higher annual rainfall increased the number of new recruits per year and growth, but decreased survival of larger recruits. The total number of natural recruits increased three-fold over the study period and varied across species. For nearly half of the species, we documented a second generation of recruits. Successes appear to be a function of time, including a changing microclimate and adaptive management practices. Remaining bottlenecks include lack of seed dispersal, and seed predation and herbivory by introduced species. The success at Ka'ūpūlehu highlights the potential for TDF restoration and the value of a biocultural approach.
\end{abstract}

Keywords: biocultural restoration; Ka'ūpūlehu; Hawaii; TDF; recruitment; endangered species

\section{Introduction}

Tropical dry forests (TDFs) are among the most at-risk ecosystems globally [1], and they continue to experience some of the highest rates of forest-cover loss [2]. Deforestation for agriculture and pastureland, wildfire, and resource extraction are among the leading causes of TDF loss [1,3].

Tropical dry forest in Hawai'i was once described as the most diverse type of forest in the Hawaiian archipelago [4]. Today more than 90\% of TDF in Hawai'i has been lost [5]. Ninety percent of Hawaiian dry forest species are endemic, and $45 \%$ are listed as federally threatened or endangered [6]. This accounts for over $25 \%$ of all endangered plant species in Hawai' $i$, and $38 \%$ of all endangered and threatened plant species in the United States [7,8].

Hawaii's TDFs have a long history of use. The early Hawaiians arrived in about 400 A.D. and designated much of low-elevation zones as wao kanaka (human settlement zone), where humans worked and cultivated the landscape $[9,10]$. TDFs provided a wide diversity of plant materials used for tools, vessels, food gathering, fishing, shelter, medicines and rituals [11]. Still, an analysis of human-transformed areas across pre-Western-contact Hawai'i show a geospatial footprint of less than $15 \%$ of total land area [12]. 
With the arrival of new settlers and cultures from Europe and Asia to Hawai'i starting in 1778, Hawaiian TDFs underwent massive land use changes [12]. This included large-scale habitat destruction for the establishment of pastures and ranching in the mid1800s, along with the introduction of invasive plants and animals, including grass species such as fountain grass (Cenchrus setacemus) and ungulates. Today wildfire is a major threat [13]. The loss and/or decline of native pollinators and seed dispersers, and high seed predation by introduced animals, especially rats [14], have also contributed to declining plant populations.

For the past two decades, however, restoration initiatives have been implemented across the Hawaiian islands in some of the few remaining TDF patches (see [15-19]). Typically in Hawai' $i$, TDF restoration involves the establishment of fencing to exclude ungulates, fire breaks to prevent wildfire, and the removal of non-native grasses; this is followed by outplanting. Across the state, thousands of common, threatened, and endangered species have been outplanted (see review [20]). Various studies have documented the benefits of grass removal on the regeneration of common native species [15,21-23]. Others have documented the survival of outplants of threatened and endangered species [24-26]. Ultimately, however, the long-term success of TDF restoration depends on the ability of outplants to regenerate naturally. This requires not only their survival and growth to adulthood, but also the functioning of ecological processes such as pollination and seed dispersal that may be needed for subsequent seed germination. To date, there is little quantitative information on if and how much natural regeneration of endangered TDF species is occurring in restored areas. A recent review also highlights the lack of quantitative studies on natural recruitment in restored TDFs at the global level [27].

Seedling recruitment in TDFs can vary with environmental conditions, especially rainfall. Recruitment tends to occur during wet seasons, while mortality is highest during dry periods $[28,29]$. However, the effects of inter-annual rainfall on seedling recruitment in TDFs remains unclear. Seedling recruitment may depend not only on current rainfall, but on rainfall from previous years [29]. In addition, while drought years may result in mortality of all new recruits, wet years may not yield the most recruitment. In a 12-year study, researchers found decreased TDF seedling recruitment in years with higher rainfall [30], potentially due to increases in seed predation, herbivory, or pathogens that may increase during wet periods [31-33]. Understanding the relationships between seedling recruitment and inter-annual patterns of rainfall is especially important in the context of climate change. In Hawai' $i$, the leeward areas where TDFs are located have become substantially drier over the past century [34], and this trend is projected to continue [35].

We are a collaborative team of researchers and dry forest managers who are monitoring the long-term natural regeneration of threatened and endangered species at Ka' ūpūlehu dryland forest, one of Hawaii's last remnant TDF patches. Ka'ūpūlehu dryland forest uses a biocultural approach to restoration, with dual, interconnected goals of restoring TDF species and re-strengthening the relationships of people to place (http:/ / www. drylandforest.org/hoola-ka-makanaa-at-kaupulehu-dryland-forest (accessed on 1 June 2021); https: / / piliaina.org/hoola-ka-makanaa-dryland-forest-at-kaupulehu (accessed on 1 June 2021)). The value of biocultural approaches to forest restoration is increasingly recognized [36-40], but outcomes remain under-reported. In a previous paper, we describe the biocultural restoration process and some of the social-ecological outcomes [19]. Here we present the ecological results of our first six annual censuses (2014-2019), which represent about 15-20 years since the first outplanting efforts of endangered species. We address the following questions: (1) Is natural regeneration of endangered species occurring? (2) If so, what are the rates of survival and growth of naturally regenerated endangered species? Do these vary as a function of rainfall? and (3) If not, where are the bottlenecks to successful regeneration? 


\section{Materials and Methods}

\subsection{Study Site}

Ka' ūpūlehu dryland forest is located on the west side of Hawai'i Island in the North Kona district on Hualālai Mountain at $600 \mathrm{~m}$ elevation, where it covers approximately 28 hectares (70 acres) (Figure 1). It is part of the ahupua'a (a social-ecological land division) of Ka'ūpūlehu, which extends from the summit of Hualālai $(2521 \mathrm{~m})$ to the ocean. It is owned by the largest private land-owner in Hawai'i, Kamehameha Schools.

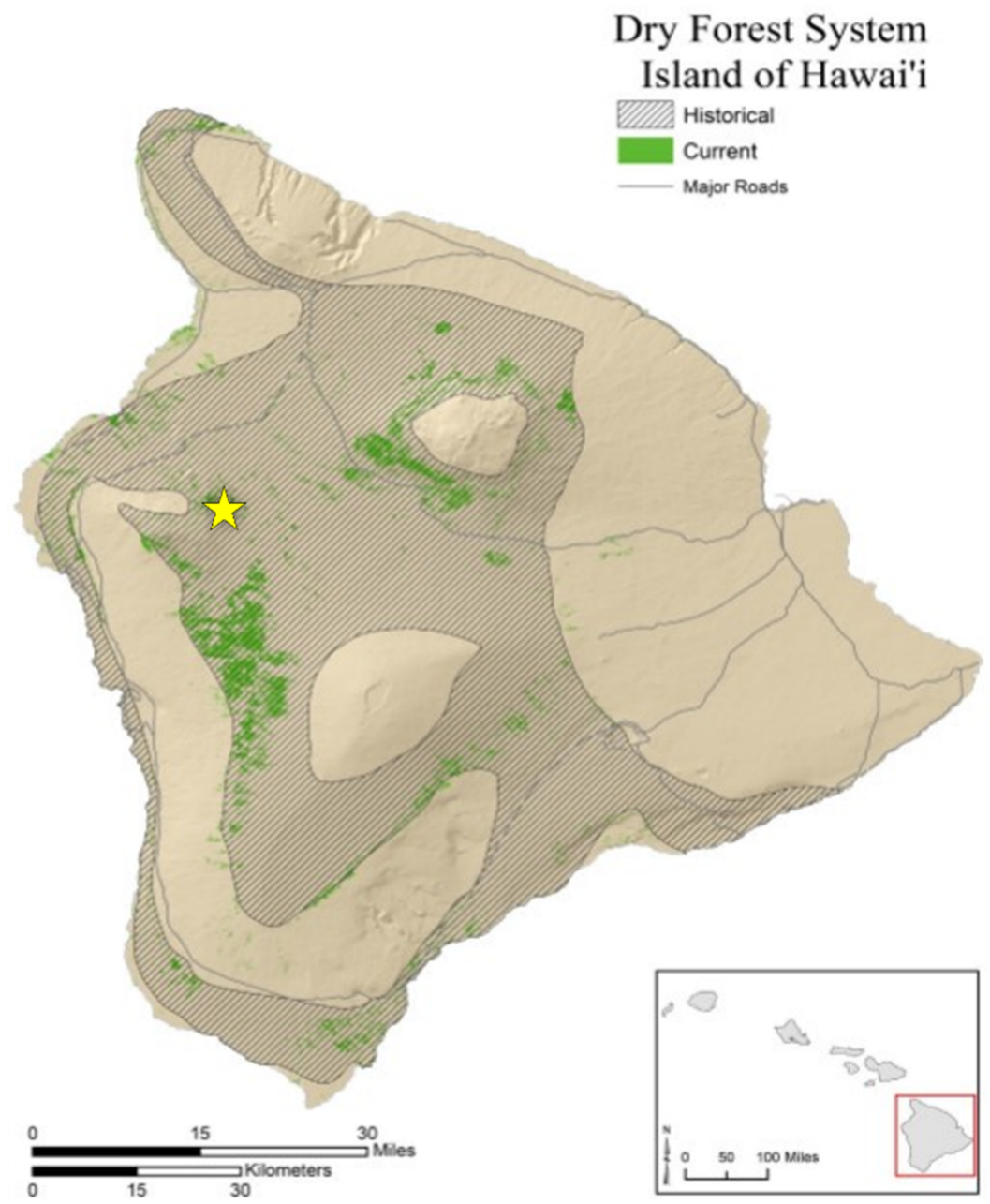

Figure 1. Location of Ka'ūpūlehu dryland forest (yellow star) on Hawai'i Island, Hawai'i, with historical and current distribution of tropical dry forest. Adapted from [41].

Efforts to protect and restore Ka'ūpūlehu dryland forest were initiated in 1995 by a small group of community members, lineal descendants, landowners, government agencies, land developers, and scientists, and the area was fenced in 1999. The site is dominated by two distinct substrates (which act as natural fuel breaks): one is where the most recent lava flow occurred in 1801 [42], and the other is an older substrate consisting of flows dating back 750 years [43]. Ōhi'a is the dominant species of the younger substrate, and lama (Diospyros sandwicensis) is the dominant species of the older substrate. Based on the 92-year record, mean annual rainfall is $714 \pm 291 \mathrm{~mm}$ (Figure 2). Despite its small size, this preserve remains one of the best native dry forest patches left in Hawai'i, hosting remnant trees of multiple endangered species. 


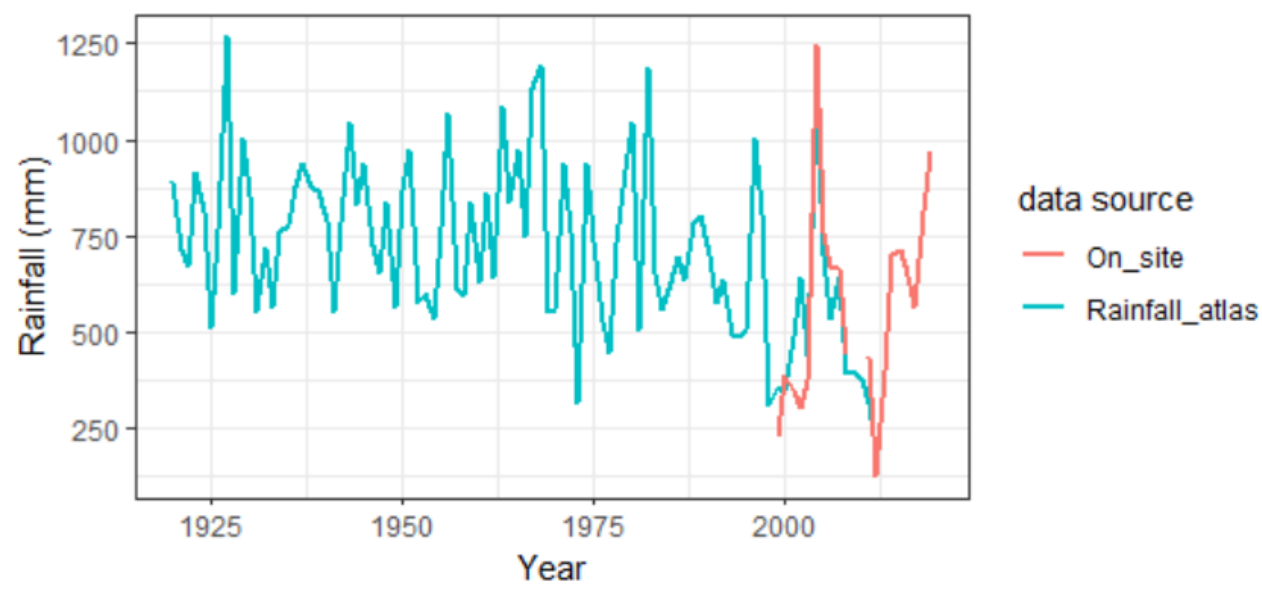

Figure 2. Annual rainfall (mm) at Ka'ūpūlehu dryland forest from 1922-2019, extrapolated from the Hawai'i Rainfall Atlas (blue) [44] and recorded on site (red).

Ka'ūpūlehu dryland forest is rich in both plant diversity and in sacred sites and historical artifacts, showing historical evidence that people and place were heavily connected. The site has engaged a biocultural method for restoration for $>20$ years by having lineal descendants in the management team, grounding management decisions within both Hawaiian and western scientific worldviews and knowledge systems, and engaging the broader community, including thousands of volunteers, in their restoration efforts [19] (https: / / piliaina.org/hoola-ka-makanaa-dryland-forest-at-kaupulehu (accessed on 17 January 2022)). The mission statement highlights the biocultural nature of the effort:

Aloha 'Āina. Aloha Ka'ūpūlehu. Aloha Wao Lama.

Far into the future,

People will feel connected

and committed to perpetuating

a functioning native landscape,

its genealogical stories and multiple truths,

and treating each other with kindness and respect.

Ka'ūpūlehu will be a healthy landscape of plenty,

alive with native plants, bird song

and history that will be tended and cherished by many.

To establish areas for restoration, non-native grasses are removed with a single herbicide application, after which, depending on the area (the existing canopy and the substrate), a strategy is developed which may feature outplanting supported by irrigation and/or physical dispersal of native seeds. Management consists of ungulate control (fence maintenance), consistent invasive plant removal, fire mitigation, native plant restoration, and educational outreach

Since its establishment, thousands of plants have been outplanted in the fenced preserve on rough lava terrain, including 12 species that are federally listed as threatened or endangered (Table 1): Aiea (Nothocestrum breviflorum), Ko'o loa 'ula (Abutilon menziesii), Ko'o ko'o lau (Bidens micrantha subsp. ctenophylla), Halapepe (Chrysodracon hawaiiensis), Kauila (Colubrina oppositifolia), Ma'o hau hele (Hibiscus brackenridgei spp. brackenridgei), Hau kuahiwi (Hibiscadelphus hualalaiensis), Aupaka (Isodendrion pyrifolium), Hau hele 'ula (Kokia drynarioides), Uhiuhi (Mezoneuron kavaiensis), Ma'aloa (Neraudia ovata), and Bonamia menziesii). Half of these are Plant Extinction Prevention Program (PEPP) species—species with fewer than 50 individuals in the wild or for which wild founders are extinct (Table 1). Approximately 10 years after the first outplantings, managers began to notice increasing regeneration of threatened and endangered species. While water supplementation and limited fertilizer are provided to outplanted individuals, most naturally regenerated seedlings are not irrigated. An exception is Mezoneuron kavaiensis, which emerge from seedbanks and, following initial emergence, are at times irrigated. 
Table 1. Endangered species, according to the US Endangered Species Act (ESA), outplanted at Ka'ūpūlehu dryland forest.

\begin{tabular}{|c|c|c|c|c|c|c|}
\hline Scientific Name & Common Name & Family & Life Form & $\begin{array}{l}\text { Presence of Wild } \\
\text { Adults in Reserve }\end{array}$ & Year First Outplanted & $\begin{array}{c}\text { No. of Adults (Reproductive-Sized } \\
\text { Plants) in Reserve (2016) }\end{array}$ \\
\hline Colubrina oppositifolia & Kauila & Rhamnaceae & Tree & Yes & 1999 & 144 \\
\hline Mezoneuron kavaiensis* & Uhiuhi & Fabaceae & Tree & Yes & 1999 & 5 \\
\hline Chrysodracon hawaiiensis & Halapepe & Asparagaceae & Tree & Yes & 2000 & 199 \\
\hline Kokia drynarioides * & Hau Hele ‘Ula & Malvaceae & Small tree/Shrub & Yes & 1999 & 62 \\
\hline Hibiscus brackenridgei subsp. Brackenridgei * & Ma’o Hau Hele & Malvaceae & Small tree/Shrub & Yes & 2001 & 44 \\
\hline Hibiscus hualalaiensis * & Hau Kuahiwi & Malvaceae & Shrub & Yes & 2003 & 11 \\
\hline Bidens micrantha subsp. Ctenophylla & Ko'oko'olau & Asteraceae & Shrub & No & 2002 & NA \\
\hline Neraudia ovata & Ma'aloa & Urticaceae & Shrub & No & 2011 & NA \\
\hline Isodendrion pyrifolium * & Aupaka & Violaceae & Small shrub & Yes & 2010 & 4 \\
\hline Bonamia menziesii & NA & Convolvulaceae & Woody vine & No & 1999 & NA \\
\hline
\end{tabular}

* PEPP (Plant Extinction Prevention Program) species are those with $<50$ individuals in the wild or with no wild founders. 


\subsection{Monitoring Recruitment, Survival, and Growth}

We identified, tagged, and measured all naturally regenerated individuals of our study species across the restored portion of Ka'ūpūlehu dryland forest (about 21 ha) over six annual censuses from 2014-2019 (Figure 3). Ka'ūpūlehu resource managers flag all new seedlings observed throughout the year. Given that managers are on the ground working in the reserve every day, consistently weeding across the restored area, and are on the look-out for new seedlings, they are able to capture most of the seedlings in the large area. In addition, the seedlings of our study species are distinctive and therefore easy to identify from the early stages. At our annual monitoring censuses at the end of December/early January, we visit all tagged individuals, and tag all new recruits that had been flagged in the year as well as any newly observed recruits. Tagging consists of tying an aluminum tag to small flag and placing it at the base of each seedling.

a)

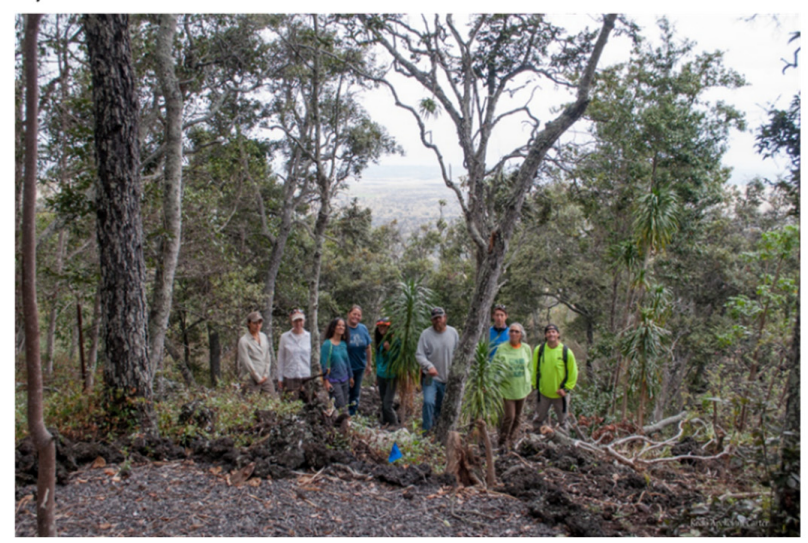

b)

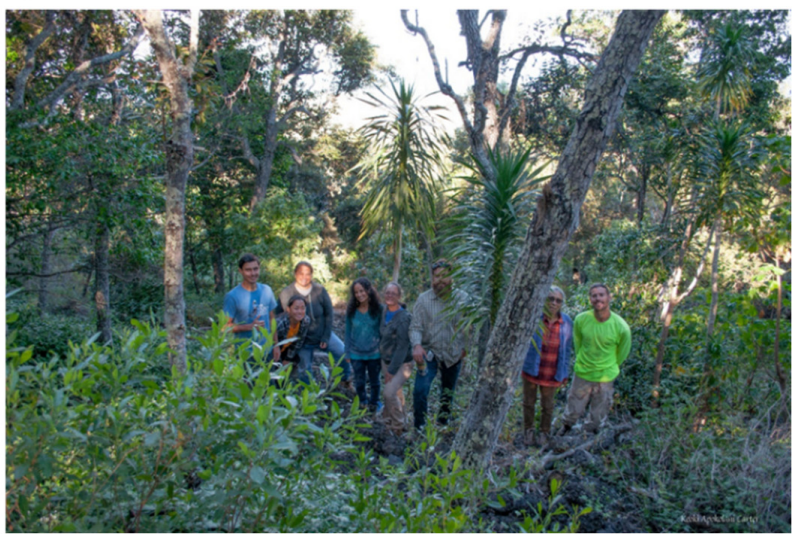

Figure 3. Members of our collaborative team during annual monitoring of natural recruits at Ka'ūpūlehu dryland forest in 2016 (a) and 2018 (b). The small trees in the forefront are natural recruits of the endangered tree, Chrysodracon hawaiiensis (halapepe). Note the growth of these trees over the two-year period.

For each plant $>10 \mathrm{~cm}$ height, we record species name, height (from the ground to the top of the apical meristem), diameter at breast height (for individuals $>1.37 \mathrm{~m}$ height), basal diameter, distance to the presumed parent plant, parent tag ID, survival status, observations of health (including intensity of herbivory), presence of flowers and/or fruit, and GPS waypoints.

Given that by 2017 there were over one thousand B. micrantha natural recruits, we stopped counting the entire population and modified our census approach for that species by setting up permanent plots to subsample recruitment, survival, and growth. For $I$. pyrifolium, to avoid stepping on and damaging plants, we counted all recruits in each patch and for each group of three plants we randomly tagged only one to measure growth and survival.

To test if recruitment (number of new recruits at each annual census) and survival and growth of natural recruits were correlated with rainfall, we used general and generalized linear mixed models. For growth, we used a Gaussian distribution with a log transformation of height. We focused on individuals $<1.5 \mathrm{~m}$ high since change in height is not an accurate measure of growth after this point, as individuals are increasing in girth (dicot trees) and/or branching (shrubs). We visually inspected model residuals to check for normality and homogeneity of the variance. To model the number of new recruits at each census and survival, we used negative binomial and binomial (binary) distributions, respectively. For all models, we included species as a random factor to account for potential differences across species. Since growth included repeated measurements of the same individuals, we also included individuals nested within species as a random factor in that model. To determine whether annual rainfall (over the census period), or rainfall over the past two 
annual census periods was a better predictor, we compared model fit using AIC values. For all three variables (growth, survival, and number of new recruits/year) we found that models with annual rainfall over the census period as a predictor had lower AIC values, and report only those model results here. All models were run using the glmmTMB package (version 1.1.2.3) [45] in R. (version 4.1.1).

\section{Results}

\subsection{Natural Recruitment of Endangered Species}

We observed natural recruits for all endangered species except $N$. breviflorum (aiea). The most prolific was B. micrantha (ko'oko'olau), a short-lived, woody plant which generated hundreds of new recruits each year. In 2017 the number of naturally regenerated individuals was 1246, two orders of magnitude higher than the other species. Since we stopped monitoring the entire population at this point, this species is excluded from the analyses below.

For the remaining 10 species, the total number of new recruits per year ranged from 61 in 2016 to nearly three times as many, 177, in 2019 (Figure 4). A few species recruited consistently, including C. oppositifolia (kauila), H. brackenridgei (ma'o hau hele), B. mensiezii, M. kavaiensis (uhiuhi), and I. pyrifolium (aupaka). At the other end of the spectrum, C. hawaiiensis (halapepe) produced no seedlings over the study period (although recruits that had been produced earlier were monitored throughout our study). The rest of the species recruited sporadically and at low levels (Figure 4). Some of the species with few reproductive adults (H. hualalaensis (hau kuahiwi) and A. mensiezii (ko'oloa'ula)) produced few seedlings. However, some of the species with many $(>50)$ reproductive-aged outplants (C. hawaiiensis and K.drynarioides (hau hele'ula)) also produced few seedlings (Table 1).

Except for M. kavaiensis, a large tree species for which very few outplants had reached reproductive size, and C. hawaiiensis, observed recruitment was from seed produced by outplants.

The total number of new recruits recorded per year increased significantly with annual rainfall $(t=0.02 ; p=0.05$; Table $S 1)$, such that each $10 \mathrm{~cm}$ of rainfall translated into approximately 20 additional recruits per year.

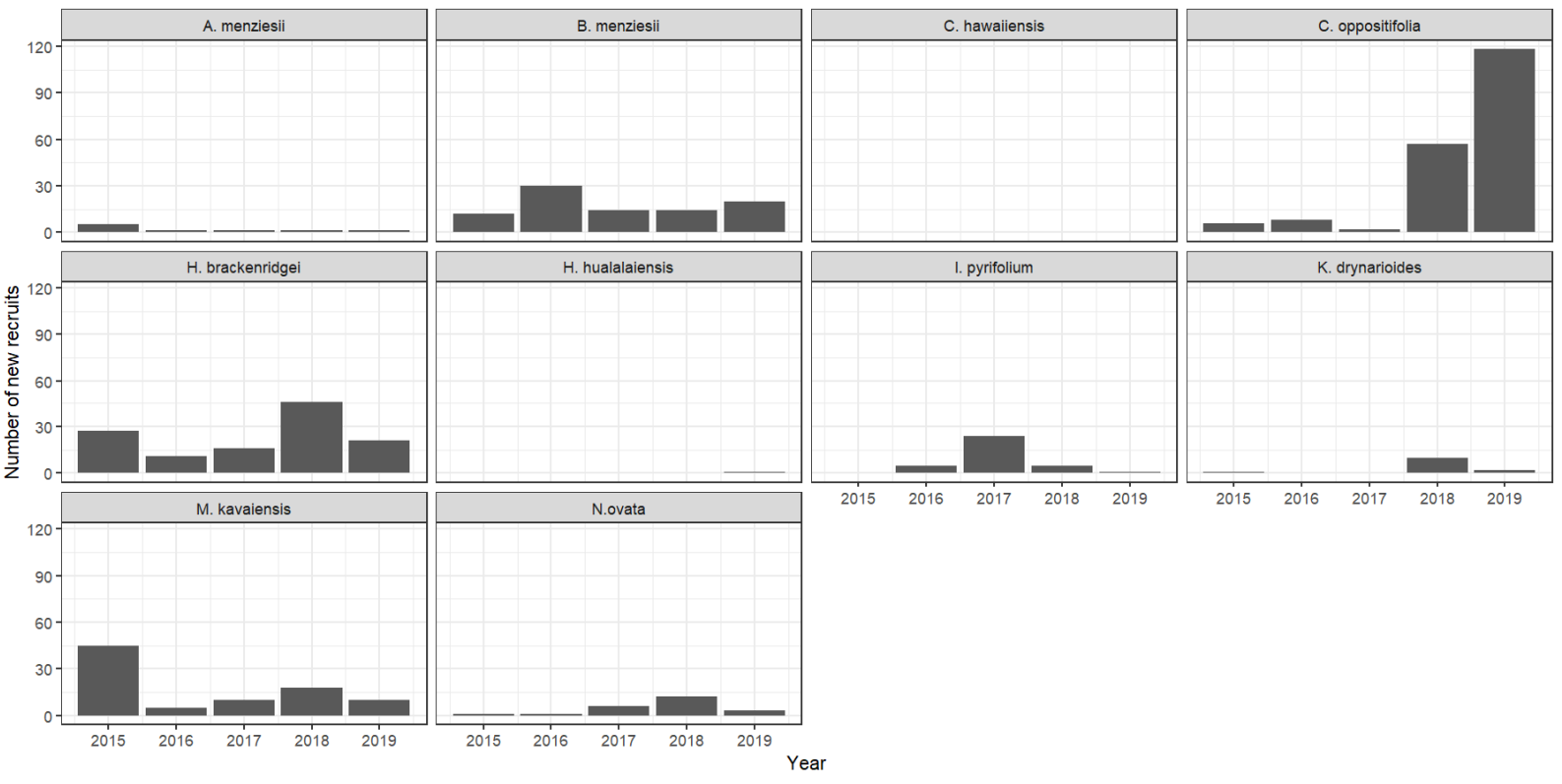

Figure 4. Number of new recruits recorded at each census, by species, at Ka'ūpūlehu dryland forest.

The total number of naturally regenerated individuals alive at each census rose threefold over our five-year study period, from 163 individuals at the end of 2014 to 451 individuals at the end of 2019/start of 2020 (Figure 5). The relative increase varied across species. C. oppositifolia, H. brackenridgei, and B. menziesii increased steadily over time. $M$. kavaiensis 
and I. pyrifolium numbers increased and then decreased. The other species maintained low but steady numbers over time (A. menziesii, C. hawaiiensis, H. hualalaiensis, K. drynarioides, and N. ovata).

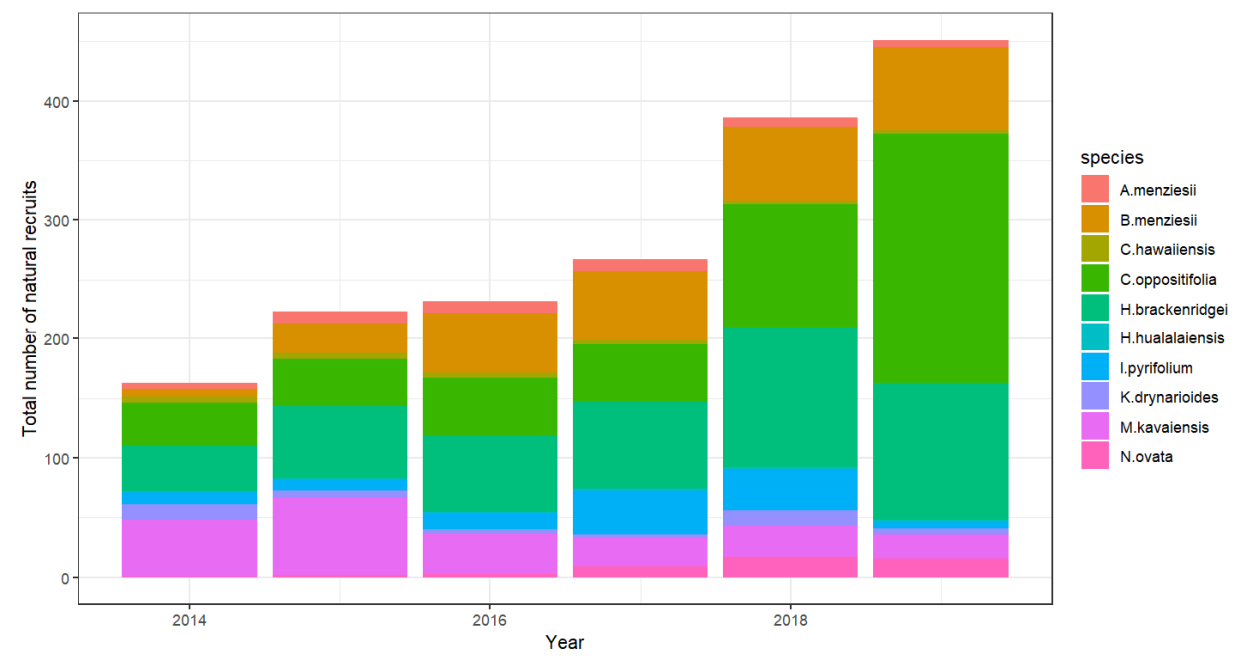

Figure 5. Total number of naturally regenerated plants alive at each annual census at Ka'ūpūlehu dryland forest.

\subsection{Survival of New Recruits}

Survival of natural recruits increased significantly with size, ranging from about $40 \%$ in recruits $<20 \mathrm{~cm}$ in height, to $90-100 \%$ for those $>50 \mathrm{~cm}$ in height (Figure 6a). Both survival rates and the relationship between size and survival varied across species (Figure 6b). For some species, such as $K$. drynarioides, survival was very low until recruits reached about $75 \mathrm{~cm}$ high, after which survival was close to $100 \%$. For others, such as H. brackenridgei and C. oppositifolia, the survival rate of seedlings $<50 \mathrm{~cm}$ was higher than that of other species of the same height and continued to increase with size until plants were about $100 \mathrm{~cm}$, at which point it was $90 \%$ or higher. For M. kavaiensis, survival was much lower and increased more slowly with size. For example, while individuals $1 \mathrm{~m}$ high of the three latter species had $\geq 80 \%$ annual survival, this value was $<60 \%$ for $M$. kavaiensis. Other species showed no apparent relationship between size and survival. I. pyrifolium had high survival from 2014-2018 and then a crash in 2019 (Figure S1).
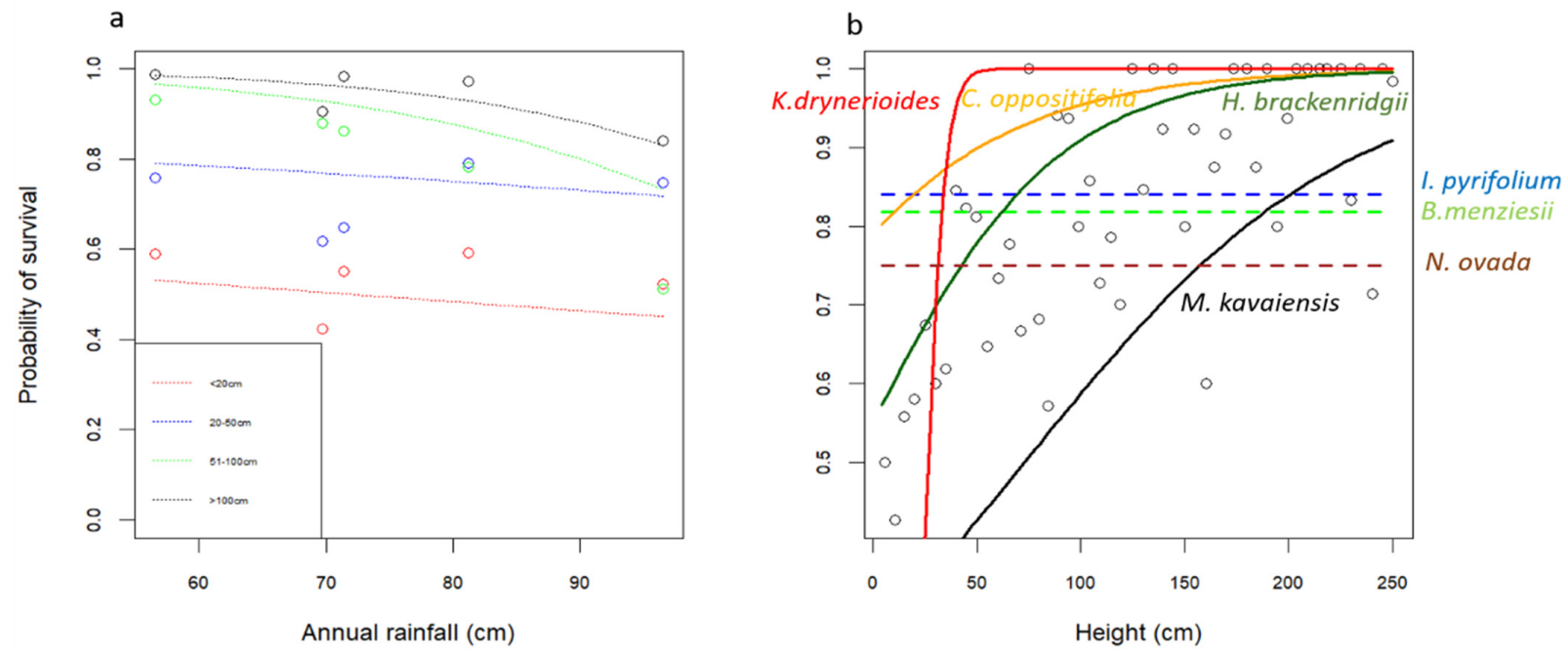

Figure 6. Probability of survival of naturally regenerated individuals at Ka'ūpūlehu dryland forest as a function of (a) annual rainfall (all species combined) and (b) height. Dots represent the proportion of individuals (all species combined) surviving in each $5 \mathrm{~cm}$ size-class bin. 
Survival of natural recruits decreased with increasing rainfall, but only for individuals $>50 \mathrm{~cm}$ (Figure 6a; height * rainfall interaction; $t=0.0004 ; p=0.002$; Table S1).

\subsection{Growth of New Recruits}

Growth, in terms of change in height, also varied across species (Figure 7). The fastestgrowing natural recruits were C. oppositifolia, H. brackenridgei, and I. pyrifolium. For all species, after they reach about $1.5 \mathrm{~m}$ high, annual increases in height are no longer good measures of growth as at that point dicots are increasing in girth, and shrubby species are growing through the production of new branching. Nonetheless, by our last census, all tree and shrub species had at least some individuals that were taller than $2 \mathrm{~m}$, with those of C. oppositifolia and H. brackenridgei reaching $4 \mathrm{~m}$ in height or more. The exception was $I$. pyrifolium, which is a small shrub that does not grow to that height.
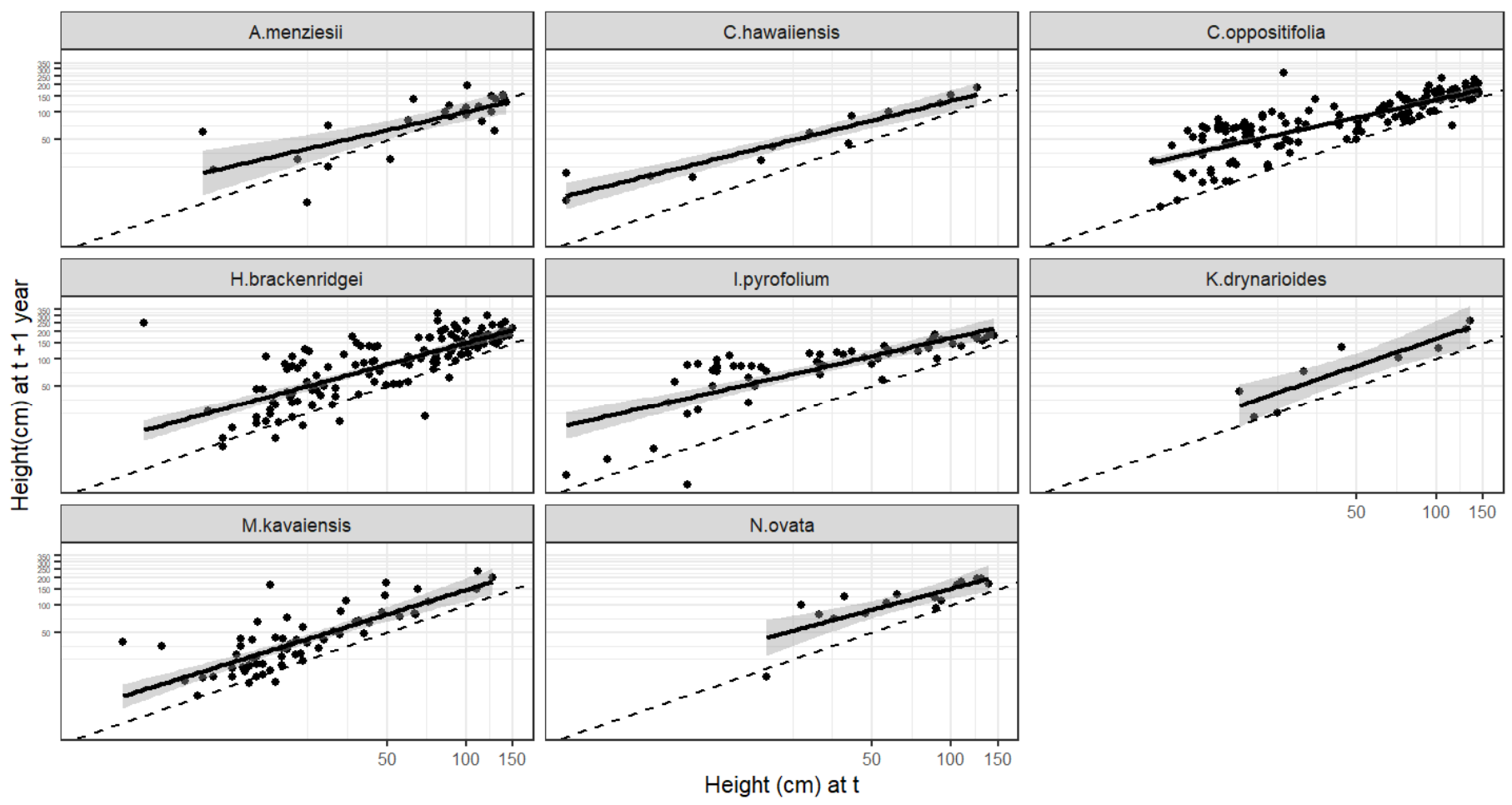

Figure 7. Annual growth of naturally recruited individuals $<150 \mathrm{~cm}$ in height at time $t$, by species, at Ka'ūpūlehu dryland forest from 2014-2019. The dotted line represents zero change in size from $t$ to $t+1$; faster growth is evidenced by points higher above the dotted line. H. hawaiiensis is not shown because of the low number of individuals.

Across all species combined, growth increased significantly with increased annual rainfall ( $t=0.004 ; p=0.007$; Table S1). The increase was about $4 \mathrm{~cm} /$ year for each $10 \mathrm{~cm}$ increase in rainfall, such that the difference between the driest year and the wettest year in our study translated into a mean difference in annual growth of about $16 \mathrm{~cm}$.

We observed natural recruits of $H$. brackenridgei, B. micrantha, N. ovata, B. menseizii, and C. oppositifolia that had reached $>2 \mathrm{~m}$ high and fruited within 4 years or less. All except the latter had also produced new recruits of their own by the end of the study period, creating the second generation of wild recruits.

\section{Discussion}

Tropical dry forests are being actively restored across the globe, but little is known about the long-term feasibility of these projects since there is little information on natural regeneration [27]. In Hawai'i, restoration sites such as Ka'ūpūlehu dryland forest have had ungulate-free, fenced enclosures for over 15 years, intensive weed management, and are 
predominantly covered with native species. However, earlier studies documented high rates of outplant mortality [25] and regeneration only of common species [23], leading many to question the feasibility of restoring endangered species in Hawaiian TDFs. Our research has documented the presence of natural recruits for 11 of the 12 endangered species planted as part of Ka' ūpūlehu's biocultural restoration, resulting in increasing numbers, and for nearly half of the species a second generation of natural recruits.

The growing natural regeneration of endangered species we documented is likely the result of multiple factors. The first significant factor is time. Time since restoration is a strong predictor of forest restoration success [46], and short-term studies, especially if they span periods of adverse conditions such as drought, can be misleading over the long-term. A meta-analysis of restoration projects for threatened plant species showed that recruitment lags ranged from four to 17 years and were longest for long-lived species [47]. In Ka'ūpūlehu, it took time for a sufficient number of outplanted individuals to survive, reach maturity, and to produce sufficient seed. The low numbers of recruits of $A$. menziesii and $H$. hualalaiensis are likely due in part to the low numbers of reproductive outplants. The shortest-lived species, $B$. micranthes, has, so far, increased most rapidly.

A second factor, related also to time, is a changing microclimate due to the restoration process. The removal of invasive grasses increases soil moisture, which in turn increases rates of germination and survival [22]. In addition, over time, Ka'ūpūlehu dryland forest has increasingly developed an understory and shrub layer of common native species that have changed microsite conditions. Previous research at Ka'ūpūlehu suggested that an understory shrub layer may be important in providing the conditions necessary for seedling establishment and growth [23,48], as is the case elsewhere [49]. In the Auwahi dry forest restoration project on Maui, shrub nurse plants and the establishment of a shrub understory have had the strongest benefits on regeneration of native tree species, specifically by enhancing germination and seedling survival [16].

A third factor is the adaptive management practiced by Ka'ūpūlehu managers. For example, in contrast to many other restoration initiatives, managers limit herbicide to a single initial treatment. Although this is more labor-intensive in terms of weeding, it allows native seedlings to emerge once the competition from invasive plants is alleviated and conditions become more favorable. Managers also observed that the exposure of areas formerly covered with grasses led to germination of $M$. kavaiensis seedbanks in areas where M. kavaiensis kupuna ('elder') trees had died. (M. kavaiensis is our only study species to form seedbanks.) As such, Ka'ūpūlehu managers now leave in place and map these iwi la'au (bones of plants/trees) to serve as markers to watch and care for seedling regeneration. Ka' ūpūlehu managers have also increased control of rodents. In 2015, 10 Goodnature A24 rat traps were installed in areas that included many C. oppositifolia kupuna ('elder') trees. C. oppositifolia seeds are heavily predated by rats, and the reduction in predation likely contributed to the increase in regeneration of this species, as natural regeneration occurred especially in those areas with traps [20].

\subsection{Effects of Rainfall on Natural Regeneration}

A fourth factor that can help explain the rapidly increasing number of natural recruits of endangered species is the absence of drought over the five-year study period. Previous drought periods ( 1998-2000 and 2008 2013) have led to high mortality of outplants [25]. Comparing weather data for the past 20 years, all five years of our study had above-mean annual rainfall (Figure 1); however, this region has become 6-8\% drier per decade since 1920 [34]. As a result, while there were no drought years, only the last two years of our study had rainfall above the 92-year mean.

On the other hand, our results suggest that higher annual rainfall had mixed effects on regeneration. Higher annual rainfall increased the number of new recruits/year as well as their growth, but it decreased survival of larger recruits. Since we monitored only once per year, the higher number of new recruits may be due to multiple factors, including increased fruit production, higher germination and/or higher survival of newly germinated 
seeds until the time of our census. Increased germination and growth of seedlings with higher rainfall is consistent with the fact that seedling recruitment occurs during the wet season in TDFs [28], as well as with previous observations that natural regeneration at $\mathrm{Ka}$ 'upūlehu requires wet years [15], and that seedling survival and growth increase with soil moisture [22].

The lower survival of larger/older recruits (>50 cm in height) with higher rainfall is at least partly due to higher rates of herbivory by non-native insects, including ants and the aphids and mealybugs they tend, which we observed especially at the end of 2018 and 2019 - the two highest rainfall years in our study and the second and third wettest years in the last 20 years. Research in Mexico [30] documented lower recruitment in rainy years in a Mexican TDF regenerating from pasture, and attributed it to likely increases in seed predation, herbivory, or pathogens during wet periods. This increased mortality due to increased insect herbivory was also observed in outplants at Ka'ūpūlehu when rainy years followed drought (Y.Y.C, personal observation). In our study, the largest effects were observed for I. pyrifolium, where the very high mortality rates appear to have been caused by a pathogen that thrived in the very humid conditions that were generated in the understory, although this was not confirmed.

\subsection{Bottlenecks in Natural Regeneration}

For close to half of the endangered species outplanted, including the large tree $C$. oppositifolia, the large shrub/small tree H. brackenridgeii, the smaller shrubs $B$. micrantha and N. ovata, and the woody vine B. menziesii, restoration appears to be highly successful, with consistent annual recruitment, high rates of survival, increasing numbers, and, with the exception of $C$. oppositifolia which requires a much longer generation time, a second generation of natural recruits.

The other species appear to face one or more of three key bottlenecks that occur at different stages along the regeneration cycle. The first is seed dispersal. Hawaiian TDFs have lost many of the native birds that provided pollination and dispersal [50], with introduced bird species only able to disperse small-seeded species [51]. C. hawaiiensis produced no new seedlings over the study period, despite the presence of adults throughout the reserve with abundant fruit and viable seeds. This species is insect-pollinated, but produces seed evolved for bird-dispersal. We observed non-native birds feeding on the fleshy exterior of the fruits, but the hard-interior seed was left intact on the parent plant, where they remain for over a year, at which point they are dry and have lost viability. $N$. breviflorum, the one species for which we observed no recruits, also produces seeds that were bird-dispersed in the past. In addition, its pollinator, a moth, is endangered [52]. We note that all five of the species with high regeneration in our study are insect-pollinated and wind-dispersed. Hand-dispersal may be needed for C. hawaiiensis, and could potentially also improve regeneration of other species with large seeds that were previously dispersed by birds.

A second bottleneck is seed predation. In TDFs, seeds remain on the forest floor until a rain event that provides favorable conditions for germination. In Hawaiian TDFs, undispersed seeds (those that fall beneath the parent tree) are especially prone to predation by introduced rodents [14]. K. drynarioides and M. kavaiensis produced abundant seeds but we observed both to be heavily predated by rats. These species may need a higher intensity of rodent control for regeneration to occur as compared to C. oppositifolia, which has many more adult trees in the reserve (Table 1) and which produces many more seeds per tree.

Finally, for those seeds that are dispersed and germinate before predation, a third bottleneck is heavy rates of herbivory on seedlings and saplings by non-native insects. Non-native insects are considered a threat to Hawaiian TDFs, but little research has been performed [53]. Insect herbivory appears to be a bottleneck for M. kavaiensis and K. drynarioides in particular, but also a problem for the three other Malvaceae. M. kavaiensis is subject to ants which excavate the roots and tend mealybugs and aphids which feed on the stems. The seedlings tend to fall over and die once they grow to about $40-50 \mathrm{~cm}$. The 
large amounts of nectar produced by $K$. drynariodes' large flowers also attract ants, which tend aphids and mealybugs on that species, too. In addition, although not observed in our study, the banana moth (Opogona sacchari) and the black twig borer (Xylosandrus compactus) are a major threat to $C$. hawaiiensis and C. oppositifolia, respectively $[54,55]$.

Identifying appropriate management to address herbivory by non-native insects is likely more complicated than addressing the two previous bottlenecks. Our previous work [56] found that insect herbivory is higher in areas with a more open canopy, and it is possible that as the restoration process continues and the canopy fills in, insect herbivory levels may gradually decrease. However, future research to assess the potential to reduce herbivory levels through companion planting [57], increasing resistance though management of the microbiome [58], and/or other methods will be important.

\section{Conclusions}

Overall, our research indicates that 15-20 years after the first restoration efforts, natural recruitment of endangered species at Ka' ūpūlehu dryland forest is rapidly increasing, with a second generation of natural recruits for multiple species that appear to be well on their way to recovery. For those species with bottlenecks in regeneration, our collaborative monitoring has pointed a way forward in terms of both management and research.

The success to date of natural recruitment seen at Ka'ūpūlehu highlights the value of a biocultural approach to restoration [19]. Ka'ūpūlehu managers hold the dual, interconnected goals of restoring dry forest species and restrengthening the relationships of people to place ('âina). Equal effort is placed on both aspects of recovery because one cannot succeed without the other. The $>1000$ natural recruits we monitored over the past five years sprung from outplants that were planted by thousands of volunteers-stewards and learners, from youth aged 13 and older, to college and community members. These volunteers have contributed to the ecological successes and at the same time reported the many ways - spiritual, cultural, and physical — in which their experiences of being in the forest provided them with social benefits and connected them deeply to place [19]. This is true for both indigenous and non-indigenous volunteers [19]. Many volunteers have returned many times. The regeneration of Ka'ūpūlehu dryland forest's endangered plants also represents the return of the stories of place, both new and old, and the reconnection to those who have cared for it for generations and those who will continue to do so.

You live, so I live.

Above and below.

Seen and unseen.

Out of sight

or shining bright.

Vibrating.

Beneath

the forest floor

and high

on the winds,

fluttering through leaves.

Generations of dryland forest,

ebb and flow,

through drought and drenchings.

Unassuming strength and patience

bridges realms,

seen and unseen.

Will the surviving five or ten percent

transition with the others?

Or stay?

Who will answer the call of the forest? 
There are signs.

Hope and new possibilities.

Rekindled by knees and eyes to the ground,

to honor and learn from place,

sweat dripping from brow,

pulling weeds, planting seeds,

counting, noting, life and mortality.

Hopeful.

Here

there is a collective growth

of kinship ties-collaborating

with place and each other.

Kuleana.

From near and far.

So it is.

Resilience and vitality

ebbs and flows.

I ola 'oe, iola mākou nei You live, and so I may live

Maluna, i lalo Above, below.

Lana, piholo Float, sink.

-2021 Yoonne Yarber Carter

Glossary of Hawaiian terms:

'Āina = Place. The seen and unseen. The heard and unheard. The inter-connectedness of atmosphere, air, waters, land, and all living things.

'Ohana $=$ Family

Kuleana $=$ Commitment and Responsibility to care for place

Wao Lama=Place of lama (Diospyros sandwicensis)

Supplementary Materials: The following are available online at https:/ / www.mdpi.com/article/10 .3390/su14031159/s1, Figure S1: Annual survival of naturally recruited individuals, by species; Table S1: Results of statistical models.

Author Contributions: Conceptualization, T.T. and Y.Y.C.; methodology, T.T. and Y.Y.C.; software, R.L., A.Y.S. and T.T.; validation, T.T.; formal analysis, R.L., A.Y.S. and T.T.; investigation, R.L., A.Y.S., L.A., W.P.B., Y.Y.C., K.A.C., K.T. and T.T.; data curation, R.L., A.Y.S. and T.T.; Writing-original draft preparation, R.L., A.Y.S. and T.T.; Writing-review and editing, R.L., A.Y.S., L.A., W.P.B., Y.Y.C., K.A.C., K.T. and T.T.; visualization, R.L., A.Y.S. and T.T.; supervision, T.T. and Y.Y.C.; project administration, T.T.; funding acquisition, R.L., A.Y.S., T.T. and Y.Y.C. All authors have read and agreed to the published version of the manuscript.

Funding: This research was funded by the United States Geological Survey Award \#G15AC00251 to R.L. and T.T., a Hau'oli Mau Loa Foundation fellowship to A.Y.S., and the Ka'ūpūlehu Foundation.

Institutional Review Board Statement: Not applicable.

Informed Consent Statement: Not applicable.

Data Availability Statement: The dataset presented in this study is available on request from the corresponding author. The full data is stored jointly by the research and management team, but not publicly available due to the sensitive nature of information on endangered species.

Acknowledgments: We thank L. Bremer, K. Kamelamela, K. Keakealani, N. Kurashima, L. Oliveira, S. Quazi, M. Thomas, L. Tomich, M. Wong, K. Afong, R. Souza, and P. West for help in the field, Alexandra Moore and hui for collaboration on outplant and permanent plot monitoring from 2008-2016, Jim Jacobi for providing support and advice; Kamehameha Schools for permission to conduct research on their lands, and three anonymous reviewers for comments on a previous version of this manuscript. 
Conflicts of Interest: The authors declare no conflict of interest. The funders had no role in the design of the study, in the collection, analyses, or interpretation of data, in the writing of the manuscript, or in the decision to publish the results.

\section{References}

1. Miles, L.; Newton, A.C.; DeFries, R.S.; Ravilious, C.; May, I.; Blyth, S.; Kapos, V.; Gordon, J.E. A global overview of the conservation status of tropical dry forests. J. Biogeogr. 2006, 33, 491-505. [CrossRef]

2. Hansen, M.C.; Potapov, P.V.; Moore, R.; Hancher, M.; Turubanova, S.A.; Tyukavina, A.; Thau, D.; Stehman, S.V.; Goetz, S.J.; Loveland, T.R.; et al. High-resolution global maps of 21st-century forest cover change. Science 2013, 342, 850-853. [CrossRef] [PubMed]

3. Sanchez-Azofeifa, G.A.; Quesada, M.; Rodriguez, J.P.; Nassar, J.M.; Stoner, K.E.; Castillo, A.; Garvin, T.; Zent, E.L.; Calvo-Alvarado, J.C.; Kalacska, M.E.; et al. Research Priorities for Neotropical Dry Forests1. Biotropica 2005, 37, 477-485. [CrossRef]

4. $\quad$ Rock, J.F. The Indigenous Trees of the Hawaiian Islands; T. H.: Honolulu, HI, USA, 1913.

5. $\quad$ Bruegmann, M.M. Hawai'i's dry forests. Endanger. Species Bull. 1996, 11, 26-27.

6. Pau, S.; Gillespie, T.W.; Price, J.P. Natural history, biogeography, and endangerment of Hawaiian dry forest trees. Biodivers. Conserv. 2009, 18, 3167-3182. [CrossRef]

7. Sakai, A.K.; Wagner, W.L.; Mehrhoff, L.A. Patterns of Endangerment in the Hawaiian Flora. Syst. Biol. 2002, 51, 276-302. [CrossRef] [PubMed]

8. U.S. Fish and Wildlife Service (USFWS). Environmental Conservation Online. System: Species Search. Available online: https: / / ecos.fws.gov / ecp0/reports/ad-hoc-species-report-input (accessed on 11 February 2021).

9. Mueller-Dombois, D. The Hawaiian ahupua 'a land use system: Its biological resource zones and the challenge for sil-vicultural restoration. Bishop Mus. Bull. Cult. Environ. Stud. 2007, 3, 23-33.

10. Winter, K.B.; Lincoln, N.K.; Berkes, F. The Social-Ecological Keystone Concept: A Quantifiable Metaphor for Understanding the Structure, Function, and Resilience of a Biocultural System. Sustainability 2018, 10, 3294. [CrossRef]

11. HFIA. Hawai'i's Dryland Forests. Hawai'i Forest Industry Association. Web. 11 March 2011. 2007. Available online: http: / / www.Hawai \T1 \textquoterightiforest.org/reports/dryland.html (accessed on 11 February 2021).

12. Gon, S.M.; Tom, S.L.; Woodside, U. Āina Momona, Honua Au Loli-Productive Lands, Changing World: Using the Hawaiian Footprint to Inform Biocultural Restoration and Future Sustainability in Hawai'i. Sustainability 2018, 10, 3420. [CrossRef]

13. Trauernicht, C.; Pickett, E.; Giardina, C.P.; Litton, C.M.; Cordell, S.; Beavers, A. The Contemporary Scale and Context of Wildfire in Hawai'i. Pac. Sci. 2015, 69, 427-444. [CrossRef]

14. Chimera, C.G.; Drake, D.R. Could poor seed dispersal contribute to predation by introduced rodents in a Hawaiian dry forest? Biol. Invasions 2011, 13, 1029-1042. [CrossRef]

15. Cabin, R.J.; Weller, S.G.; Lorence, D.H.; Flynn, T.W.; Sakai, A.K.; Sandquist, D.; Hadway, L.J. Effects of Long-Term Ungulate Exclusion and Recent Alien Species Control on the Preservation and Restoration of a Hawaiian Tropical Dry Forest. Conserv. Biol. 2000, 14, 439-453. [CrossRef]

16. Medieros, A.C.; VonAllmen, E.I. Restoration of Native Hawaiian Dryland Forest at Auwahi, Maui; U.S. Geological Survey (USGS) Fact Sheet No. 2006-3035; USGS: Reston, VA, USA, 2006. [CrossRef]

17. Ammondt, S.A.; Litton, C.M.; Ellsworth, L.M.; Leary, J.K. Restoration of native plant communities in a Hawaiian dry lowland ecosystem dominated by the invasive grass Megathyrsus maximus. Appl. Veg. Sci. 2013, 16, 22-39. [CrossRef]

18. Wada, C.A.; Bremer, L.L.; Burnett, K.; Trauernicht, C.; Giambelluca, T.; Mandle, L.; Parsons, E.; Weil, C.; Kurashima, N.; Ticktin, T. Estimating Cost-Effectiveness of Hawaiian Dry Forest Restoration Using Spatial Changes in Water Yield and Landscape Flammability Under Climate Change. Pac. Sci. 2017, 71, 401-424. [CrossRef]

19. Sato, A.Y.; Ticktin, T.; Alapai, L.; von Allmen, E.I.; Brawner, W.P.; Carter, Y.Y.; Carter, K.A.; Keakealani, R.K.; Medeiros, A.C.; Zahawi, R.A. Biocultural restoration of Hawaiian tropical dry forests. Pac. Conserv. Biol. 2021, 27, 362-375. [CrossRef]

20. Sato, A.Y. Restoration of Hawaiian Tropical Dry Forests: A Biocultural Approach. Master's Thesis, University of Hawai'i at Manoa, Manoa, HI, USA, 2020.

21. Litton, C.M.; Sandquist, D.R.; Cordell, S. Effects of non-native grass invasion on aboveground carbon pools and tree population structure in a tropical dry forest of Hawaii. For. Ecol. Manag. 2006, 231, 105-113. [CrossRef]

22. Thaxton, J.M.; Cordell, S.; Cabin, R.J.; Sandquist, D.R. Non-Native Grass Removal and Shade Increase Soil Moisture and Seedling Performance during Hawaiian Dry Forest Restoration. Restor. Ecol. 2012, 20, 475-482. [CrossRef]

23. Thaxton, J.M.; Cole, T.C.; Cordell, S.; Cabin, R.J.; Sandquist, D.R.; Litton, C.M. Native Species Regeneration Following Ungulate Exclusion and Nonnative Grass Removal in a Remnant Hawaiian Dry Forest. Pac. Sci. 2010, 64, 533-544. [CrossRef]

24. Cabin, R.J.; Weller, S.G.; Lorence, D.H.; Cordell, S.; Hadway, L.J.; Montgomery, R.; Goo, D.; Urakami, A. Effects of Light, Alien Grass, and Native Species Additions on Hawaiian Dry Forest Restoration. Ecol. Appl. 2002, 12, 1595-1610. [CrossRef]

25. Cordell, S.; McClellan, M.; Carter, Y.Y.; Hadway, L.J. Towards restoration of Hawaiian tropical dry forests: The Kaupulehu outplanting programme. Pac. Conserv. Biol. 2008, 14, 279-284. [CrossRef]

26. Burney, D.A.; Burney, L.P. Monitoring results from a decade of native plant translocations at Makauwahi Cave Reserve, Kaua'i. Plant Ecol. 2016, 217, 139-153. [CrossRef] 
27. Dimson, M.; Gillespie, T.W. Trends in active restoration of tropical dry forest: Methods, metrics, and outcomes. For. Ecol. Manag. 2020, 467, 118150. [CrossRef]

28. Khurana, E.; Singh, J.S. Ecology of seed and seedling growth for conservation and restoration of tropical dry forest: A review. Environ. Conserv. 2001, 28, 39-52. [CrossRef]

29. Maza-Villalobos, S.; Balvanera, P.; Martínez-Ramos, M. Early Regeneration of Tropical Dry Forest from Abandoned Pastures: Contrasting Chronosequence and Dynamic Approaches. Biotropica 2013, 43, 666-675. [CrossRef]

30. Martínez-Ramos, M.; Balvanera, P.; Villa, F.A.; Mora, F.; Maass, J.M.; Méndez, S.M. Effects of long-term inter-annual rainfall variation on the dynamics of regenerative communities during the old-field succession of a neotropical dry forest. For. Ecol. Manag. 2018, 15, 91-100. [CrossRef]

31. Marquis, R.J.; Diniz, I.R.; Morais, H.C. Patterns and correlates of interspecific variation in foliar insect herbivory and pathogen attack in Brazilian cerrado. J. Trop. Ecol. 2001, 17, 127-148. [CrossRef]

32. Cuevas-Reyes, P.; Quesada, M.; Hanson, P.; Dirzo, R.; Oyama, K. Diversity of gall-inducing insects in a Mexican tropical dry forest: The importance of plant species richness, life-forms, host plant age and plant density. J. Ecol. 2004, 92, 707-716. [CrossRef]

33. Sloan, S.A.; Zimmerman, J.K.; Sabat, A.M. Phenology of Plumeria alba and its Herbivores in a Tropical Dry Forest. Biotropica 2007, 39, 195-201. [CrossRef]

34. Frazier, A.G.; Giambelluca, T.W. Spatial trend analysis of Hawaiian rainfall from 1920 to 2012. Int. J. Clim. 2017, 37, $2522-2531$. [CrossRef]

35. Timm, O.E.; Giambelluca, T.W.; Diaz, H.F. Statistical downscaling of rainfall changes in Hawai'i based on the CMIP5 global model projections. J. Geophys. Res. Atmos. 2015, 120, 92-112. [CrossRef]

36. Kimmerer, R.W. Braiding Sweetgrass: Indigenous Wisdom, Scientific Knowledge and the Teachings of Plants; Milkweed Editions: Minneapolis, MN, USA, 2013.

37. Marks-Block, T.; Lake, F.K.; Bird, R.B.; Curran, L.M. Revitalized Karuk and Yurok cultural burning to enhance California hazelnut for basketweaving in northwestern California, USA. Fire Ecol. 2021, 17, 1-20. [CrossRef]

38. Kurashima, N.; Jeremiah, J.; Ticktin, T. I Ka Wā Ma Mua: The Value of a Historical Ecology Approach to Ecological Restoration in Hawai'i. Pac. Sci. 2017, 71, 437-456. [CrossRef]

39. Memorandum on Indigenous Traditional Ecological Knoweldge and Federal Decision Making (15 November 2021). Available online: https:/ / www.whitehouse.gov /ceq/news-updates/2021/11/15/white-house-commits-to-elevating-indigenousknowledge-in-federal-policy-decisions / (accessed on 11 January 2021).

40. Lyver, P.O.B.; Akins, A.; Phipps, H.; Kahui, V.; Towns, D.R.; Moller, H. Key biocultural values to guide restoration action and planning in New Zealand. Restor. Ecol. 2016, 24, 314-323. [CrossRef]

41. Reeves, M.K.; Amidon, F. Habitat Status Assessment Methods-Hawai i, Current Condition Summaries; Technical Report from United States Fish and Wildlife Service; Pacific Islands Fish and Wildlife Office: Honolulu, HI, USA, 2018; p. 439.

42. Kauahikaua, J.; Cashman, K.; Clague, D.; Champion, D.; Hagstrum, J. Emplacement of the most recent lava flows on Hualalai Volcano, Hawai'i. Bull. Volcanol. 2002, 64, 229-253. [CrossRef]

43. Wright, T.L.; Chun, J.Y.F.; Esposo, J.; Heliker, C.; Hodge, J.; Lockwood, J.P.; Vogt, S.M. Map Showing Lava Flow Hazard Zones, Island of Hawai' $i$; Miscellaneous Field Studies Map MF-2193; US Geological Service: Reston, VA, USA, 1992.

44. Giambelluca, T.W.; Chen, Q.; Frazier, A.G.; Price, J.P.; Chen, Y.-L.; Chu, P.-S.; Eischeid, J.K.; Delparte, D.M. Online Rainfall Atlas of Hawai'i. Bull. Am. Meteorol. Soc. 2013, 94, 313-316. [CrossRef]

45. Brooks, M.E.; Kristensen, K.; van Benthem, K.J.; Magnusson, A.; Berg, C.W.; Nielsen, A.; Skaug, H.J.; Maechler, M.; Bolker, B.M glmmTMB Balances Speed and Flexibility Among Packages for Zero-inflated Generalized Linear Mixed Modeling. R J. 2017, 9, 378-400. Available online: https://journal.r-project.org/archive/2017/RJ-2017-066/index.html (accessed on 6 September 2021). [CrossRef]

46. Crouzeilles, R.; Curran, M.; Ferreira, M.S.; Lindenmayer, D.B.; Grelle, C.E.V.; Benayas, J.R. A global meta-analysis on the ecological drivers of forest restoration success. Nat. Commun. 2016, 7, 1-8. [CrossRef]

47. Albrecht, M.A.; Osazuwa-Peters, O.L.; Maschinski, J.; Bell, T.J.; Bowles, M.L.; Brumback, W.E.; Duquesnel, J.; Kunz, M.; Lange, J.; McCue, K.A.; et al. Effects of life history and reproduction on recruitment time lags in reintroductions of rare plants. Conserv. Biol. 2019, 33, 601-611. [CrossRef] [PubMed]

48. Cabin, R.J.; Weller, S.G.; Lorence, D.H.; Cordell, S.; Hadway, L.J. Effects of microsite, water, weeding, and direct seeding on the regeneration of native and alien species within a Hawaiian dry forest preserve. Biol. Conserv. 2002, 104, 181-190. [CrossRef]

49. Vieira, D.L.; Scariot, A. Principles of natural regeneration of tropical dry forests for restoration. Restor. Ecol. 2006, 14, 11-20. [CrossRef]

50. Boyer, A.G. Extinction patterns in the avifauna of the Hawaiian islands. Divers. Distrib. 2008, 14, 509-517. [CrossRef]

51. Chimera, C.G.; Drake, D.R. Patterns of Seed Dispersal and Dispersal Failure in a Hawaiian Dry Forest Having Only Introduced Birds. Biotropica 2010, 42, 493-502. [CrossRef]

52. Elliott, C.H.; Gillett, C.P.D.T.; Parsons, E.; Rubinoff, D. Conservation conundrum: Endangered species persists on noxious weed Biotropica 2021, 53, 1265-1269. [CrossRef]

53. Gregg, R.M. Hawaiian Islands Climate Vulnerability and Adaptation Synthesis; EcoAdapt: Bainbridge Island, WA, USA, 2018.

54. Frazier, A.G.; Deenik, J.L.; Fujii, N.D.; Funderburk, G.R.; Giambelluca, T.W.; Giardina, C.P.; Helweg, D.A.; Keener, V.W.; Mair, A.; Marra, J.J.; et al. Managing Effects of Drought in Hawai'i and US-Affiliated Pacific Islands. In Effects of Drought on 
Forests and Rangelands in the United States; Translating Science into Management Responses; Vose, J.M., Peterson, D.L., Luce, C.H., Patel-Weynand, T., Eds.; Gen. Tech. Rep. WO-98; Department of Agriculture Forest Service, Washington Office: Washington, DC, USA, 2019; Chapter 5, pp. 95-121.

55. Javar-Salas, C.M.; Pe'a, R.; Amidon, F.; Reeves, M.K.; Miller, S.E. Hawaiian Islands Dry Forest. In Encyclopedia of the World's Biomes; Elsevier: Amsterdam, The Netherlands, 2020; pp. 295-327. [CrossRef]

56. Libby, R. Factors That Affect Natural Regeneration, Growth, and Survival Rates of Threatened and Endangered Species in Dryland Forests in Hawai'i. Master's Thesis, University of Hawai'i at Mānoa, Mānoa, HI, USA, 2018.

57. Parker, J.E.; Snyder, W.E.; Hamilton, G.C.; Rodriguez-Saona, C. Companion planting and insect pest control. Weed Pest Control. Conv. New Chall. 2013, 10, 55044.

58. Chock, M.K.; Hoyt, B.; Amend, A.S. Mycobiome Transplant Increases Resistance to Austropuccinia psidii in an Endangered Hawaiian Plant. Phytobiomes J. 2021, 5, 326-334. [CrossRef] 